Литвинчук Алла Іванівна кандидат психологічних наук, доцент кафедри психології, Поліський національний університет, вул. Пушкінська, 40, м. Житомир, 10001, тел.: (097) 357-44-71, e-mail: lytvynchukalla@gmail.com, https://orcid.org/0000-0001-9805-7416

\title{
ПСИХОЛОГІЧНІ ОСОБЛИВОСТІ УЯВЛЕНЬ ПРО НЕБЕЗПЕКУ ОСІБ ЯКІ ПРОЖИВАЮТЬ У СІЛЬСЬКІЙ МІСЦЕВОСТІ
}

Анотація. У статті обгрунтовано актуальність та доцільність дослідження психологічних особливостей уявлень про небезпеку осіб які проживають у сільській місцевості. Метою дослідження є емпіричне вивчення психологічних особливостей уявлень про небезпеку осіб які проживають у сільській місцевості. Аналізуються уявлення жителів сільської місцевості про актуальні асоціативні ряди щодо феномену «небезпека».

Нині населення України вимушене пристосовуватись до постійних трансформацій та змін навколишнього середовища (як економіко-соціального, так i природного). Тому було сформульовано припущення про те, що населення сільської місцевості сприймає поняття «небезпека» через конкретні об'єктивні поняття та визначення, які описують їх щоденний побут, а суб'єктивні переживання, рефлексія - знаходяться на другорядних позиціях.

Наведено результати емпіричного дослідження психологічних особливостей уявлень про небезпеку осіб які проживають у сільській місцевості. Здійснено порівняльний аналіз уявлень про поняття «небезпека» особами які проживають у сільській місцевості. Встановлено, що асоціації на слово-стимул «небезпека» мають статистично значущі відмінності. Визначено групи слів-асоціацій, які об'єднані за критеріями суб'єктивності-об'єктивності та абстрактностіконкретності.

Проаналізовано, що асоціації на слово-стимул «небезпека» можна виокремити в наступні категорії: конкретні поняття (явища об’єктивної дійсності), абстракті характеристики, особистісно-значущі уявлення. На основі асоціацій створено ієрархію асоціацій на слово-стимул «небезпека». Визначено, що основною асоціацією $є$ абстрактне поняття за критерієм абстрактності «страх», за критерієм особистісно-значущих уявлень - «смерть», за критерієм конкретних понять - «пожежа». Виявлені статеві відмінності в уявленнях про небезпеку: чоловіки частіше асоціюють поняття «небезпека» із конкретними 
поняттями, жінки - 3 абстрактними характеристиками та особистісно-значущими категоріями. Визначено, що рівень суб'єктивного відчуття психологічної небезпеки жінок значущо вищій, ніж чоловіків.

Ключові слова: психологічна безпека, психологічна небезпека, рівень урбанізованості, суб'єктивна небезпека.

Lytvynchuk Alla Ivanivna, Candidate of Psychological Sciences (Ph. D.), Associate Professor at the Department of Psychology, Polissia National University, Pushlinska St., 40, Zhytomyr, 10001, tel.: (097) 357-44-71, e-mail: lytvynchukalla@gmail.com, https://orcid.org/0000-0001-9805-7416

\section{PSYCHOLOGICAL PECULIARITIES OF THE DANGER CONCEPTS OF PERSONS RESIDING IN RURAL AREAS}

Abstract. The article substantiates the relevance and expediency of the study of the psychological characteristics of the ideas about the danger of people living in rural areas. The aim of the study is to empirically study the psychological characteristics of the perceptions of the danger of people living in rural areas. The ideas of rural residents about the actual associative series regarding the phenomenon of "danger" are analyzed.

Now the population of Ukraine is forced to adapt to constant transformations and changes in the environment (both economic, social and natural). Therefore, it was suggested that the population of rural areas perceives the concept of "danger" through specific objective concepts and definitions that describe their daily life, and subjective experiences, reflection - are in secondary positions.

The results of an empirical study of the psychological characteristics of the perceptions of the danger of people living in rural areas are presented. A comparative analysis of the concept of "danger" by persons living in rural areas is carried out. It was found that associations to the stimulus word "danger" have statistically significant differences. The groups of words-associations, united according to the criteria of subjectivity-objectivity and abstractness-concreteness, have been determined.

It is analyzed that associations to the word-stimulus "danger" can be divided into the following categories: concrete concepts (phenomena of objective reality), abstract characteristics, personally significant ideas. On the basis of associations, a hierarchy of associations was created for the stimulus word "danger". It was determined that the main association is an abstract concept according to the criterion of abstractness "fear", according to the criterion of personally significant ideas - "death", according to the criterion of concrete concepts - "fire". Revealed gender differences in perceptions of danger: men more often associate the concept of "danger" with specific concepts, women - with abstract characteristics and personality-significant categories. It was 
determined that the level of subjective feeling of psychological danger in women is significantly higher than in men.

Keywords: psychological security, psychological danger, the level of urbanization, subjective danger.

Постановка проблеми. Нині населення України постало перед низкою різноманітних проблем: економічних, соціальних, інформаційних, психологічних. Змінюючи організацію своєї життєдіяльності особистість або пристосовується до змін, або піддається їх негативному впливові, що деструктивно позначається на їі психологічній стійкості та витривалості.

Впродовж вищеназваному пристосуванню формується система особистісних суб'єктивних способів протистояти різноманітним небезпекам. Найбільш якісно це проявляється у особистісних смислах, тобто значеннях, які людина приписує тій чи іншій події чи явищу у своєму житті. Тому особливо важливим $\epsilon$ вивчення тих смислів, які транслюються через мовлення та описують життя людини.

Для розвитку стійкого до непередбачуваних та різких соціальних змін суспільства необхідно враховувати актуальний рівень почуття безпеки (захищеності) та небезпеки у осіб які проживають у місцях різного рівня урбанізованості. Припускаємо, що особи які проживають у сільській місцевості матимуть специфічні уявлення про поняття «небезпека», вони відрізнятимуться у осіб які мають різний рівень інтегральної безпеки.

Аналіз останніх досліджень і публікацій. Різноманітні аспекти понять «психологічна небезпека», «небезпека», «психологічна безпека», «безпека» стають предметом пошуків багатьох науковців, зокрема психологів. Особливо популярними темами є вивчення особливостей безпечної поведінки та безпечного життя особистості. Так, Н. С. Уханова зазначає, що «із поняттям “безпека" асоціюється стан та почуття перебування в безпеці, відсутність тривоги чи стурбованості, упевненість, стабільність» [1. С.92]. Розглядаючи феномен безпеки, психологи доходять висновку, що у масовій свідомості це явище асоціюється як з “відсутністю загроз”, так і з актуальним станом, емоціями та переживаннями людей [2].

Психологічна небезпека досить часто описується як противага психологічній безпеці та стабільності [1, 2]. Виокремлюються певні характеристики психологічної безпеки: сталість, здатність опиратися зовнішнім впливам, здатність швидкої рекреації, здатність до рефлексії, позитивне світобачення, усвідомлення власної значущості, тощо [3].

Щодо поняття «небезпека» чи «психологічна небезпека», то його означення $є$ 
дещо звуженим. Так психологічну небезпеку розглядають, як стан напруженості, невизначеності та потенційного або актуального загрозливого стану особистості $[3,4]$, або як деструкцію особистості з можливістю, або без ії подальшого відновлення. Розглядаються загальні джерела психологічної небезпеки: зовнішні (негативний вплив оточуючого природного або соціального середовища) та внутрішні (наприклад аутоагресія) чинники.

Однак наукові пошуки у сфері вивчення психологічних особливостей уявлень про небезпеку, зокрема, осіб які проживають у сільській місцевості поки що не систематизовані і не досліджені в повному обсязі, що і зумовило вибір теми дослідження [3, 4].

Мета статті - емпіричне вивчення психологічних особливостей уявлень про небезпеку осіб які проживають у сільській місцевості.

Виклад основного матеріалу. Методи дослідження. Вивчення психологічних особливостей уявлень про небезпеку осіб які проживають у сільській місцевості реалізовувалось як складова частина фундаментального дослідницького проекту вивчення особливостей психологічної безпеки особистості. Емпіричний збір даних відбувався з жовтня 2020 до січня 2021 року. Участь у дослідженні взяли особи які проживають у сільській місцевості ( $\mathrm{N}=148$ ) 3 них 98 жінок $(66,2 \%)$ та 50 чоловіків $(33,8 \%)$. Вік респондентів коливається в межах 21-65 років, найбільшу частину становлять респонденти віком 21-45 років (76\%), 26 респондентів віком 46-60 років (18\%) та 7 респондентів віком 61-65 років (7\%). Залучені до дослідження респонденти проживають у сільській місцевості Житомирської (86\%), Дніпропетровської, Запорізької (8\%), Київської (2\%), Закарпатської (2\%), Вінницької (2\%) областей, що дає змогу стверджувати про репрезентативність вибірки регіональному об'єднанню України.

Для вивчення психологічних особливостей уявлень про небезпеку осіб які проживають у сільській місцевості респондентам було запропоновано перелік запитань та вільних асоціацій. Його валідність та надійність забезпечувалась використанням методу незалежних експертних оцінок. Опитувальник містив запитання спрямовані на відчуття субєктивної безпеки в різних сферах життя, створення асоціативного ряду на слово-стимул «небезпека».

Для якісного та кількісного аналізу асоціацій використано метод експертних оцінок. Для статистичної обробки одержаних кількісних даних застосовувались методи математичної статистики (описова статистика, порівняння залежних вибірок (t-критерій Стьюдента), ранговий кореляційний аналіз Спірмена). Автоматизована обробка даних проводилась за допомогою пакету програм IBM SPSS Statistics 26 та програмного середовища ArcGIS.

Результати та дискусії. За результатами емпіричного дослідження виявлена кількісна та смислова ієрархія асоціацій на словосполучення «небезпека». Аналіз 
результатів свідчить, що у осіб які проживають у сільській місцевості словостимул «небезпека» має широкий ряд асоціацій (див. табл. 1).

Якісний аналіз дозволив стверджувати, що загалом у респондентів слово «небезпек» асоціюється із «страхом» (12\%), «смертю» (9\%), «вогнем» (6\%) та пожежею «5\%».

Аналізуючи смислову ієрархію асоціативних рядів було встановлено, що перші асоціації, які є зазвичай стереотипними та останні, які відображають особистісно-значущі асоціації, значущо між собою не відрізняються. Для жителя сільської місцевості небезпека $є$ страхом за яким криється щось невідоме та незрозуміле, що породжує нерозуміння та невпевненість.

Встановлено, що існують статеві відмінності в уявленнях про небезпеку: чоловіки частіше асоціюють поняття «небезпека» із конкретними поняттями, жінки - 3 абстрактними характеристиками та особистісно-значущими категоріями. Визначено, що рівень суб'єктивного відчуття психологічної небезпеки жінок значущо вищій, ніж чоловіків.

Таблиия 1.

Особливості асоціацій на слово-стимул «небезпека»

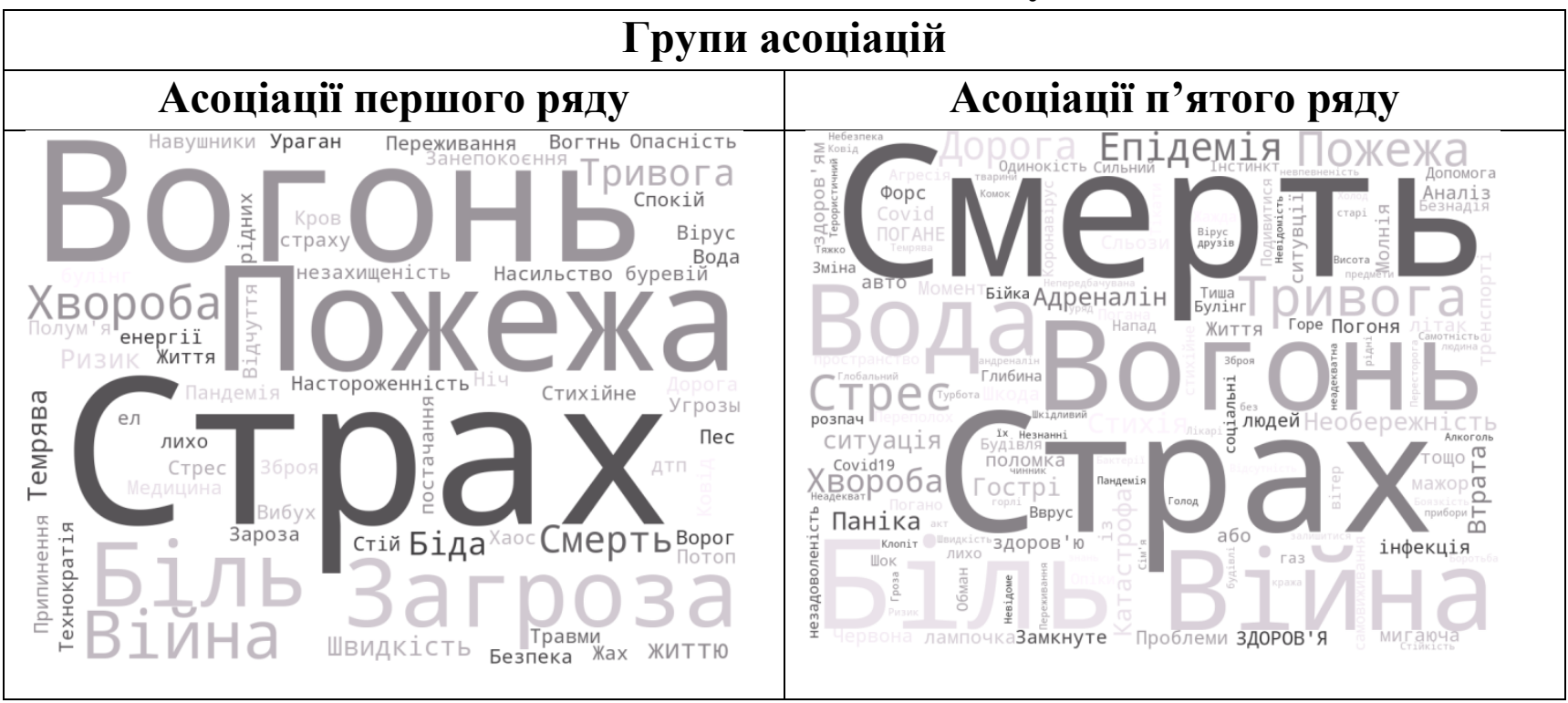

Якісний аналіз асоціацій на основі методу експертних оцінок та ранжування і каталогізації дозволив здійснити їх якісну характеристику.

За допомогою експертних оцінок асоціації були розподілені на три категорії, що дозволило об’єднати їх в три групи «абстрактні поняття», «особистіснозначущі уявлення» та «конкретні поняття». До абстрактних асоціацій віднесені ті, які мають яскраво виражену метафоричність, абстрактність, ті, які не належать до явищ об’єктивної дійсності, наприклад «страх», «тривога», «загроза», «спокій», «настороженість» тощо. До особистісно-значущих уявлень асоціацій віднесені ті, які репрезентують суб'єктивну оцінку респондента «хвороба близької людини», 
«булінг дітей», тощо. До групи конкретних понять віднесені ті асоціації, які мають виражену предметність. С частиною матеріального світу, наприклад «вода», «пожежа», «хвороба», «війна», «смерть», тощо. Для кількісного аналізу кожній групі асоціацій був присвоєний числовий індекс (Value): «1»= «абстрактні», «2»= «особистісно-значущі Уявлення», «3»= «конкретні поняття»). Було застосовано методи статистичної обробки даних і встановлено, що асоціації осіб, які проживають у сільській місцевості за вищеназваним критеріями мають різний рівень значущості $(\mathrm{t}=3,601 ; \mathrm{p} \leq 0,011)$ (див. табл. 2).

Таблиия 2.

Відмінності асоціацій до слова «небезпека» осіб які проживають у сільській місцевості

\begin{tabular}{|c|c|c|c|c|c|c|c|c|}
\hline \multicolumn{9}{|c|}{ Paired Samples Test } \\
\hline \multirow{4}{*}{ 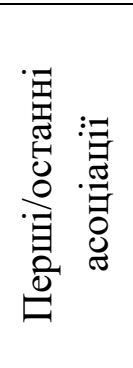 } & \multicolumn{5}{|c|}{ Paired Differences } & \multirow{3}{*}{$\mathrm{t}$} & \multirow{3}{*}{$\mathrm{df}$} & \multirow{3}{*}{$\begin{array}{c}\text { Sig. } \\
\text { 2-tailed }\end{array}$} \\
\hline & \multirow[t]{2}{*}{ Mean } & \multirow{2}{*}{$\begin{array}{l}\text { Std. } \\
\text { Deviati } \\
\text { on }\end{array}$} & \multirow[t]{2}{*}{$\begin{array}{l}\text { Std. } \\
\text { Error } \\
\text { Mean }\end{array}$} & \multicolumn{2}{|c|}{$\begin{array}{c}95 \% \text { Confidence } \\
\text { Interval of the } \\
\text { Difference }\end{array}$} & & & \\
\hline & & & & Lower & Upper & & & \\
\hline & ,592 & ,848 &, 124 &, 740 &, 245 & 3,601 & 147 &, 011 \\
\hline
\end{tabular}

Найбільшу частку становлять асоціації, які знаходяться в групі «конкретні поняття». Очевидно, для сільських жителів природні катаклізми, які впливають безпосередньо на їх життя, матеріальне та соціальне благополуччя, є більш актуальними та важливими. Асоціації, які репрезентують абстрактні поняття знаходяться на другому місці. Тобто респонденти небезпеку асоціюють 3 власними переживаннями та прагненнями. На третьому місці знаходяться особистісно-значущі уявлення. Очевидно, для досліджуваних суб'єктивні уявлення про небезпеку або є менш важливими, або не рефлексуються ними, як ті, що відносяться до загального конструкту «небезпека» такі висновки співзвучні 3 деякими зарубіжними дослідженнями [4].

Для більш конкретної інтерпретації психологічних особливостей уявлень про небезпеку осіб які проживають у сільській місцевості було визначено суб'єктивний рівень відчуття психологічної безпеки досліджуваних із сільської місцевості (див. табл. 3). Загалом, досліджувані визначають свій рівень психологічної безпеки як досить низький $(\overline{\mathrm{x}}=2,710)$. Проте, спостерігаємо закономірність: респонденти у яких домінуючими асоціаціями виявились абстрактні поняття, які складно уособити та конкретизувати, мають нижчий рівень суб'єктивного відчуття безпеки, ніж респонденти у яких домінуючими асоціаціями $\epsilon$ конкретні поняття (відповідно $\overline{\mathrm{x}}=1,821, \overline{\mathrm{x}}=3,304$ ). Можна 
припустити, що можливість уособити та конкретно означити джерело небезпеки, рівень загрози здається нижчим, ніж у тих досліджуваних, які точно не можуть описати, що є для них небезпекою.

Таблицяя 3.

Рівень психологічної безпеки у респондентів за домінуючими групами асоціацій $(\overline{\mathbf{x}})$

\begin{tabular}{|c|c|}
\hline Групи асоціацій & $\begin{array}{c}\text { Інтегральний рівень } \\
\text { оезпеки }\end{array}$ \\
\hline Абстрактні поняття & 1,821 \\
\hline $\begin{array}{c}\text { Особистісно-значущі } \\
\text { уявлення }\end{array}$ & 3,006 \\
\hline Конкретні поняття & 3,304 \\
\hline Загалом & 2,710 \\
\hline
\end{tabular}

Для знаходження достовірних відмінностей між показниками суб'єктивним відчуттям безпеки у осіб, які мають різні домінуючі типи асоціативних рядів було використано обрахунки t-критерію Стьюдента (див. табл. 4). Статистично значущих відмінностей виявлено не було, проте встановлені певні тенденціі: респонденти у яких домінуючим типом асоціацій є абстрактні поняття схильні сприймати усі сфери свого життя як досить небезпечні $(\mathrm{t}=-3,832 ; \mathrm{p} \leq 0,162)$, ті, які у яких домінуючими $є$ особистісно-значущі уявлення сприймають власне життя як досить безпечне $(\mathrm{t}=-1,502 ; \mathrm{p} \leq 0,243)$. Ті ж, у кого домінують асоціації пов’язані із конкретними поняттями почувають себе досить безпечно у щоденному житті $(\mathrm{t}=3,442 ; \mathrm{p} \leq 0,157)$.

Таблиия 4.

Особливості почуття безпеки осіб які мають різні домінуючі типи асоціацій

\begin{tabular}{|c|c|c|c|c|c|c|c|c|}
\hline \multirow{3}{*}{$\begin{array}{c}\text { Групи } \\
\text { асоціацій }\end{array}$} & \multicolumn{5}{|c|}{ Paired Differences } & \multirow{3}{*}{$\mathrm{t}$} & \multirow{3}{*}{ df } & \multirow{3}{*}{$\begin{array}{c}\text { Sig. } \\
2- \\
\text { taile } \\
\text { d }\end{array}$} \\
\hline & \multirow[t]{2}{*}{ Mean } & \multirow[t]{2}{*}{$\begin{array}{l}\text { Std. } \\
\text { Devia } \\
\text { tion }\end{array}$} & \multirow[t]{2}{*}{$\begin{array}{l}\text { Std. } \\
\text { Error } \\
\text { Mean }\end{array}$} & \multicolumn{2}{|c|}{$\begin{array}{l}\text { 95\% Confidence } \\
\text { Interval of the } \\
\text { Difference }\end{array}$} & & & \\
\hline & & & & Lower & Upper & & & \\
\hline Загалом &,- 064 & 1,767 & ,335 &,- 436 & ,376 &,- 374 & 148 & ,708 \\
\hline $\begin{array}{l}\text { Абстрактні } \\
\text { поняття }\end{array}$ &,- 272 & 1,840 & ,413 & $-1,118$ & ,516 & $-3,832$ & 48 & ,162 \\
\hline $\begin{array}{l}\text { Особистісн } \\
\text { о-значущі } \\
\text { уявлення }\end{array}$ &,- 416 & 1,218 &, 175 &,- 846 & , 149 & $-1,502$ & 26 & ,243 \\
\hline $\begin{array}{l}\text { Конкретні } \\
\text { поняття }\end{array}$ & ,846 & 2,225 & ,456 &,- 742 & 2,141 & 3,442 & 74 &, 157 \\
\hline
\end{tabular}


Для більш детальної інтерпретації був використаний кореляційний аналіз Спірмена (див. табл. 5). Встановлено, що існує статистично значущий зв'язок між показниками психологічної безпеки у домінуючих групах асоціацій як респондентів загальної вибірки (r=0,367; $\rho \leq 0,001)$, так групи асоціацій «конкретні поняття» $(\mathrm{r}=0,527 ; \rho \leq 0,001)$ та групи асоціацій «абстрактні поняття» $(\mathrm{r}=-0,432 ; \rho \leq 0,05)$. Не спостерігаємо таких кореляцій у респондентів у яких домінуючою групою є «особистісно значущі уявлення».

Таблицяя 5.

\section{Взасмозв'язки показників психологічної безпеки та груп домінуючих асоціацій}

\begin{tabular}{|c|c|c|c|}
\hline \multicolumn{3}{|c|}{ Вибірка/групи асоціацій } & Безпека \\
\hline \multirow{3}{*}{$\begin{array}{l}\text { Spearman's } \\
\text { rho }\end{array}$} & \multirow{3}{*}{ Загальна вибірка } & Correlation Coefficient &, $367^{* *}$ \\
\hline & & Sig. (2-tailed) &, $537^{* *}$ \\
\hline & & $\mathrm{N}$ &, 007 \\
\hline \multirow{3}{*}{$\begin{array}{l}\text { Spearman's } \\
\text { rho }\end{array}$} & \multirow{3}{*}{ Абстрактні } & Correlation Coefficient &,$- 432^{*}$ \\
\hline & & Sig. (2-tailed) & ,060 \\
\hline & & $\mathrm{N}$ & 48 \\
\hline \multirow{3}{*}{$\begin{array}{l}\text { Spearman's } \\
\text { rho }\end{array}$} & \multirow{3}{*}{$\begin{array}{c}\text { Особистісно- } \\
\text { Значущі уявлення }\end{array}$} & Correlation Coefficient &, 237 \\
\hline & & Sig. (2-tailed) & ,207 \\
\hline & & $\mathrm{N}$ & 26 \\
\hline \multirow{3}{*}{$\begin{array}{l}\text { Spearman's } \\
\text { rho }\end{array}$} & \multirow{3}{*}{$\begin{array}{c}\text { Конкретні } \\
\text { поняття }\end{array}$} & Correlation Coefficient &, $527^{* *}$ \\
\hline & & Sig. (2-tailed) &, 076 \\
\hline & & $\mathrm{N}$ & 74 \\
\hline
\end{tabular}

В результаті дослідження визначено, що відчуття психологічної безпеки та уявлення про небезпеку у осіб які проживають в сільській місцевості мають певну специфіку.

Висновки. Психологічна небезпека визначається як стан психологічної незахищеності від зовнішніх та внутрішніх впливів. В умовах суспільних трансформацій та неперервних соціальних змін суб'єктивний рівень почуття небезпеки стрімко зростає. Встановлено особливості уявлень про небезпеку у осіб які проживають у сільській місцевості. Загалом джерелами небезпеки для них $\epsilon$ абстрактні поняття, особистісно-значущі уявлення та конкретні поняття. Існують відмінності у рівні особистої безпеки досліджуваних у яких домінують різні групи асоціацій до слова «небезпека». Найбільш безпечно себе почувають ті, хто може описати джерело небезпеки через конкретні явища об'єктивної дійсності, найменш безпечно ті асоціативний ряд яких містить абстрактні поняття. Існує статистично значущий зв’язок між відчуттям психологічної безпеки у 
респондентів з різними групами домінуючих асоціацій. Суб'єктивний рівень відчуття психологічної безпеки має загальні низькі показники.

\section{Лimepamypa:}

1. Уханова, Н. С. Інформаційно-психологічна безпека особистості, суспільства та держави. Правова інформатика, (3), 2013. 91-95.

2. Рощин С.К., Соснин В.А. Психологическая безопасность : новый подход к безопасности человека, общества и государства. Российский монитор. 1995. 6. Режим доступу : //www.bookap.by.ru/psywar/grachev/gl6.shtm

3. Edmondson, A.C. (2004). Psychological safety, trust, and learning in organizations: a grouplevel lens. In Trust and Distrust in Organizations: Dilemmas and Approaches, ed. RM Kramer, KS Cook, pp. 239-72. New York: Russell Sage.

4. Soares, André Escórcio \& Lopes, Miguel Pereira (2014). Social networks and psychological safety: A model of contagion. Journal of Industrial Engineering and Management (JIEM) [ISSN:] 2013-0953 [Volume:] 7 [Year:] 2014 [Issue:] 5 [Pages:] 995-1012. Режим доступу: http://hdl.handle.net/10419/188640

\section{References:}

1. Ukhanova, N. S. (2013). Informatsiino-psykholohichna bezpeka osobystosti, suspilstva ta derzhavy [Information and psychological security of the individual, society and state]. Pravova informatyka - Legal Informatics, (3), 91-95 [in Ukrainian].

2. Roshchin, S.K., Sosnin, V.A. (1995). Psikhologicheskaya bezopasnost: novyy podkhod k bezopasnosti cheloveka, obshchestva i gosudarstva [Psychological safety: a new approach to the safety of a person, society and state]. Rossiyskiy monitor - Russian monitor, 6. Retrieved from http://www.bookap.by.ru/psywar/grachev/gl6.shtm [in Russian].

3. Edmondson, A.C. (2004). Psychological safety, trust, and learning in organizations: a grouplevel lens. R.M. Kramer, K.S. Cook (Eds.). In Trust and Distrust in Organizations: Dilemmas and Approaches. (pp. 239-72). New York: Russell Sage [in English].

4. Soares, A. E. \& Lopes, M. P. (2014). Social networks and psychological safety: A model of contagion. Journal of Industrial Engineering and Management (JIEM), 7(5), 995-1012. Retrieved from http://hdl.handle.net/10419/188640 [in English]. 